\title{
Putting Soil Security on the Policy Agenda: Need for a Familiar Framework
}

\author{
David Oscar Yawson ${ }^{1, *}$, Michael Osei Adu ${ }^{2}$, Benjamin Ason ${ }^{3}$, Frederick Ato Armah ${ }^{4}$ and \\ Genesis Tambang Yengoh 5 \\ 1 Department of Soil Science, School of Agriculture, College of Agriculture and Natural Sciences, \\ University of Cape Coast, Cape Coast, Ghana \\ 2 Department of Crop Science, School of Agriculture, College of Agriculture and Natural Sciences, \\ University of Cape Coast, Cape Coast, Ghana; michael.adu@ucc.edu.gh \\ 3 Soil Research Institute, Council for Scientific and Industrial Research, Accra, Ghana; \\ soilresearchben@gmail.com \\ 4 Department of Environmental Science, School of Biological Science, College of Agriculture and Natural \\ Sciences, University of Cape Coast, Cape Coast, Ghana; farmah@ucc.edu.gh \\ 5 Lund University Centre for Sustainability Studies (LUCSUS), Lund University, Lund 22100, Sweden; \\ yengoh_genesis.yemgoh@lucsus.lu.se \\ * Correspondence: david.yawson@ucc.edu.gh; Tel.: +233-271-305-832
}

Academic Editor: Palmiro Poltronieri

Received: 4 July 2016; Accepted: 23 September 2016; Published: 29 September 2016

\begin{abstract}
Soils generate agricultural, environmental, and socio-economic benefits that are vital to human life. The enormity of threats to global soil stocks raises the imperative for securing this vital resource. To contribute to the security framing and advancement of the soil security concept and discourse, this paper provides a working definition and proposes dimensions that can underpin the conceptualization of soil security. In this paper, soil security refers to safeguarding and improving the quality, quantity and functionality of soil stocks from critical and pervasive threats in order to guarantee the availability, access, and utilization of soils to sustainably generate productive goods and ecosystem services. The dimensions proposed are availability, accessibility, utilization, and stability, which are obviously similar to the dimensions of food security. Availability refers to the quality and spatial distribution of soils of a given category. Accessibility relates to the conditions or mechanisms by which actors negotiate and gain entitlements to occupy and use a given soil. Utilization deals with the use or purpose to which a given soil is put and the capacity to manage and generate optimal private and public benefits from the soil. Finally, stability refers to the governance mechanisms that safeguard and improve the first three dimensions. These dimensions, their interactions, and how they can be operationalized in a strategy to secure soils are presented and discussed.
\end{abstract}

Keywords: soil security; dimensions; availability; accessibility; utilization; stability; critical and pervasive threats; ecosystem services; policy agenda

\section{Introduction}

Soil is probably the most important natural resource and biosystem that support human and terrestrial life. It is a primary, finite natural resource from which other resources, goods, and services are derived. Soils play multiple ecosystem roles, including provisioning (food, fiber), regulating (water quality), supporting (biodiversity, nutrient cycling), and cultural (historical records) roles [1]. Soils are intricately linked with and play crucial roles in biogeochemical cycles. Almost all current global challenges such as food and water security, climate change, and biodiversity loss, among others, are directly or indirectly related to soils [2]. Soil is therefore an inevitable resource for sustainable development and human security, and effort must be made to conserve global soil stocks. 
Global soil stocks face enormous pressure and threats. Global food production needs to increase substantially [3-5] to meet the demands of a projected population of over 9 billion by 2050 [6]. Two-thirds of this projected population is likely to live in urban areas, with greatest implications for land use changes and soil resources in developing countries $[7,8]$. Currently, degradative processes, unsustainable use and management practices, haphazard land use and land cover changes, and poor policy attention continue to cause alarming reductions in the quantity and quality of global soil stocks [9]. Soil erosion, acidification, salinization, depletion of nutrients and organic matter, contamination, and compaction are among the key degradative processes [2]. Cumulatively, salinization affects an estimated 955 million ha, while desertification affects about 3.5 billion ha of land in the world [10]. The annual rate and cost of soil loss through erosion and remediation of eutrophication and sedimentation of waterbodies is substantial [11-13]. What is even more dangerous is that natural soil formation substantially lags behind soil loss. Even though soil is renewable in the long term (hundreds to thousands of years to centuries), it is economically and scientifically expensive to recover or reclaim soils in the short term [2].

It is therefore reasonable and important to protect soils from dangerous erosive or degradative processes and to ensure continuous access to quality soils in the short term to guarantee long-term benefits. This imperative raises the need to bridge the gap between sustainable soil stewardship and development practice. Despite recent policy initiatives, such as the Global Soil Partnership [14] and the Intergovernmental Science-Policy Platform on Biodiversity and Ecosystem Services (IPBES) Land Degradation Assessment, the need to embed soil into key sustainable development instruments and initiatives such as the Sustainable Development Goals (SDGs) remains both elusive and urgent. This has resulted in the idea of soil security. McBratney and colleagues [15] defined soil security as concerning the maintenance and improvement of the world's soil resource to produce food, fiber, and freshwater, contribute to energy and climate sustainability, and maintain the biodiversity and the overall protection of the ecosystem. Soils should be secured to address three cross-cutting challenges: (i) balance the increasing demand for food and ecosystem services to the supply from soils; (ii) balance the competing demands and claims for soils in an equitable and just manner so that the billions of livelihoods that depend directly on soils are not disturbed beyond elastic limit; (iii) ensure sound agricultural, environmental, and socio-economic use and management of soils in response to threats to soil quality and quantity. The objective of this paper is to contribute to the evolution of the discourse on soil security by proposing the use of the food security dimensions, which will be readily accessible to a wider range of stakeholders and ease conceptualization, monitoring, and assessment of soil security to inform policy and operational decisions.

\section{Soil Security-Its Dimensions and Conceptualization}

"A nation that destroys its soil destroys itself" [16]. The changing nature and scope of threats to soil stocks requires a new approach. Framing the use of soil as a resource from an existential perspective can be a potent way to get the attention of decision-makers [17]. Framing is an integral part of agenda setting in policy circles. It uses "metaphors, catch phrases, visual images, moral appeals, and other symbolic devices" [18] to provide fresh views about an issue or justification for a proposed course of action [19]. To this end, the "security" frame has gained currency and has been useful in getting the attention of decision-makers on environmental and resource scarcity issues [20]. Examples include energy security, food security, water security, ecological security, and climate security. Soil and environmental scientists have a long history of articulating the threats to global soil stocks, but they have been less successful in enmeshing soil into development policy instruments and initiatives [21,22]. Therefore, framing soil use as a security issue (securitization) has become necessary to elevate concerns about soil from the sphere of politics or business as usual to a sphere of "panic politics" $[23,24]$ where these concerns are viewed as existential or human security threats requiring urgent, extraordinary countermeasures. 
While the definition by [15] focuses on the sustenance of productive and ecosystem services, it might not explicitly direct attention to reductions in soil quantity due to, for example, land use change. We provide a working definition of soil security. That is, soil security refers to safeguarding and improving the quality, quantity, and functionality of soil stocks from critical and pervasive threats in order to guarantee the availability, access, and utilization of soils to sustainably generate productive goods and ecosystem services. Safeguarding implies deliberate, proactive, responsive, flexible, and dynamic institutional or governance mechanisms to protect and improve soil stocks. The quality refers to a core set of soil properties or attributes that support biological, chemical, and physical processes which underpin an appropriate or a target soil functioning. This can be referred to as the vital core [25] and is specific to a given context. The quantity refers to the depth and spatial distribution of soil stocks (of a given quality, condition, or capability). Functionality refers to the ability or natural working of the soil to generate productive goods (such as food and fiber) and ecosystem services. Critical threats are those that can potentially degrade the vital core and thereby render the soil stock dysfunctional or substantially reduce the spatial coverage of soil stocks. Threats are pervasive if they are widespread and potentially recurrent at the given scale [25]. This definition broadens while keeping key elements in previous definitions $[15,26]$. It also focuses attention on key actions and goals while keeping the multi-dimensionality of soil security. It introduces critical and pervasive threats to enable identification of threats and prioritization of policy and operational actions. Overall, this definition broadens the focus to encompass the soil as a resource, the threats it faces, and the societal factors that are the major sources of vulnerability or resilience in a given jurisdiction, administrative, or spatial scale.

\subsection{Dimensions}

While framing can succeed in getting the attention of decision-makers on a given resource scarcity or environmental issue, discourse moves the issue to the agendas of decision-makers [17]. A set of dimensions can help provide a conceptual basis to enable the movement from framing to discourse and consequently generate the desired concerted and coherent action on securing global soil stocks. This set of dimensions should incorporate both the scientific or technical aspects of soil functioning on the one hand, and the human or societal factors that underpin access, use, and management of soil on the other hand. In other words, the dimensions should enable the scientific assessment of the state and functioning of soils and the monitoring of societal appropriation, exploitation, and management of soil as a resource, as well as capture the interrelated dynamic systems and the feedback mechanisms that complicate soil security.

McBratney et al. [15] proposed five dimensions of soil security with the view to providing a framework for distinguishing the assessment of the optimal state and the current state of the soil and how the soil is being effectively used. The dimensions proposed were capability (potential functionality), condition (current state of the soil), capital (monetary or economic worth of soil), connectivity (management capacity), and codification (public policy and regulation). While these dimensions have been well articulated, the overall framework still overly relies on the "science of the soil" and its technical management and, therefore, keeps soil security largely in the hands of technocrats.

Obviously, the interdependent relationship between soil and food security is more readily perceptible to decision-makers and a wide range of actors. Soil security can be conceptualized in a sense similar to food, water, and energy security [15]. Because food and soil security share a conceptual space, and since food is already securitized, we argue that soil security can have dimensions similar to food security which is already popular amongst a wide range of actors and on the agendas of decision-makers and development practitioners. We therefore propose the following dimensions for soil security: availability, accessibility, utilization, and stability (which are the same as the dimensions of food security). These dimensions can adequately address the issues of quantity, quality, access, use, and sustainability of the soil resource system. Using the proposed dimensions will enable a discourse 
in a familiar territory and avoid the risk of soil security failing to get the attention of decision-makers due to a feeling of overuse of the security frame and overwhelming number of dimensions to address. It will help soil security to benefit from some methodologies and indices of food security and make outputs of assessments of the dimensions more accessible to target actors. The dimensions would also enable easy, simple, and rapid assessment or measurement and monitoring of soil stocks by a range of actors. Finally, these dimensions make explicit the multi-institutional and stakeholder approach required to create a situation where all actors, regardless of their functions or principal objectives, ensure that their decisions and actions are coherent and do not explicitly or implicitly undermine soil security. The proposed dimensions are less detailed and less complex and, by reducing the amount of information required for operationalizing soil security, would enable policy and operational actions that are more direct and effective. From these dimensions, measurable indicators can be identified, as well as related legal, policy, and socio-economic factors. Decision-makers are familiar with the type of information they should elicit to address the proposed dimensions, while researchers can easily determine what research questions to ask. The proposed dimensions and its related issues are presented in Table 1.

Table 1. Proposed dimensions of soil security.

\begin{tabular}{cccl}
\hline Dimension & \multicolumn{1}{c}{ Aspect } & Scale & \multicolumn{1}{c}{ Questions/Issues } \\
\hline Availability & Resource endowment & Local to global & $\begin{array}{l}\text { Quantity, spatial distribution of soil } \\
\text { condition, quality or capability }\end{array}$ \\
\hline Access & Resource appropriation & Local to national & $\begin{array}{l}\text { Who has access and how or under } \\
\text { what conditions? }\end{array}$ \\
\hline Utilization & $\begin{array}{c}\text { Resource exploitation } \\
\text { and management }\end{array}$ & Local & $\begin{array}{l}\text { Purpose and benefits of use, } \\
\text { management capacity } \\
\text { (knowledge/skills of manager, } \\
\text { appropriateness and effectiveness of } \\
\text { management practices) }\end{array}$ \\
\hline Stability & $\begin{array}{c}\text { Resource governance } \\
\text { and sustainability }\end{array}$ & Local to national (global?) & $\begin{array}{l}\text { What laws, policies, institutions, } \\
\text { actors, procedures, norms, technology } \\
\text { and research are there or are needed? }\end{array}$ \\
\hline
\end{tabular}

\subsection{Availability}

Availability addresses questions regarding endowment, which comprises the quantity (areal coverage and depth) and spatial distribution of soils of a specified quality, capacity, condition, or type in a given jurisdiction. It is about inventorying and stock-taking of soils. This dimension therefore embodies the "capability" and "condition" proposed by McBratney et al. [15]. Degraded soils and degradative processes or threats that reduce the quality and quantity of soil stocks can be identified, monitored, and addressed. The availability dimension is important since soil fit for a given purpose or use must first be physically available in sufficient quantities and at the right place and time to enable its productive use. Temporal assessments or monitoring can help assess the changes that have occurred over time. Quantifying available soils in this way will present a kind of "soil balance sheet" which will ease monitoring and assessment of the "soil net worth" of a given jurisdiction, or from local to global scales. Such data or information will be attractive and useful to decision-makers at all administrative scales to readily appreciate the threats to soil stocks and to society. Information on these quantitative and qualitative changes, together with the processes, mechanisms, or drivers of these changes, will certainly be instrumental for advocacy, discourse, and securing political action to address the threats to soils. To this end, critical and pervasive threats can be identified, prioritized, and addressed to protect available soil stocks.

A soil that is eroded or degraded to the extent that it cannot support productive purposes or ecosystem services is unavailable. Rapid decline in global soil stocks has prompted the term "peak soil" [27], a term akin to "peak oil." The purpose is to highlight the manifold potential of the 
world "running out of available soils." It is proper to continue inventorying, over reasonable time periods, the per capita soil of a population in a given administrative scale or jurisdiction. Quantifying available soils based on productive uses or ecosystem services can be a useful way to show to the dependent population the need to protect the soil stocks. Soils must have a set of core properties at thresholds that confer on the given soil the capacity to perform a given function. Ensuring the continuous availability of soils in this way implies identification of critical and pervasive, direct and indirect threats to the given soil stocks.

\subsection{Accessibility}

Accessibility deals with the aspect of appropriation of soil. It addresses questions regarding who has access and the processes, mechanisms, or conditions of access to soil of a particular nature at a given place and time for a given purpose or use. Access to soil presupposes access to land and, for that matter, the right to use the soil for a particular purpose. Access to land is underpinned by several factors including economic, political, socio-cultural, and legal factors. For example, access to available soil of an acceptable quality can be constrained by poor infrastructure or socio-cultural factors. Hence, to achieve soil security, questions regarding physical, economic, socio-cultural, political, and legal conditions or factors that mediate or shape access to land and soil need to be asked. Other issues that can emerge from such questions include gender, tenure, equity, and procedural and distributive justice.

The strength and integrity of land administration systems define the ease or otherwise with which land (and for that matter soil) is accessible. Access to land and quality soil can be a major contributor to wealth creation, soil security, and sustainable development. However, in most countries, weak land administration systems imply that the conditions and mechanisms of access constrain sustainable use and management of soils, or unintentionally undermine soil security. Thus, access to land can constitute a major source of threats to soil security. Land valuation (putting a value on land, as proposed by [15]) can be embedded in stronger land administration and taxation systems while measures are taken to provide public incentives for promoting soil security. Such instruments of valuation or taxation can be particularly useful when used to constrain access that can result in, for example, land use change which undermines soil security. After all, he who has access has the right to use and the duty to manage the soil; but will that person be that right one? Therefore, in moving forward the agenda of securing soils for sustainable development, it is important to have a dimension that deals with access to soil and its mediating factors.

\subsection{Utilization}

This dimension deals with optimal exploitation and management of soil stocks. It addresses two main questions regarding use and management capacity in relation to benefits generated and soil conservation goals. The first question concerns how soil stocks are being or can be used to serve identified purposes or to generate benefits. The second concerns the capacity of soil users or managers to manage the soil as a productive resource or natural capital, as well as the appropriateness and effectiveness of management practices. That is, this embodies the combination of knowledge, skills, technology, and financial capacity of the soil manager and the suitability of active management practices. Thus, issues here should include not only the traditional, hard soil science but also "soil sociology", which incorporates the human aspects of soil use and management. Historically and traditionally, efforts and initiatives aimed at sustainable use and the management of soils have overly focused on the natural science aspect to the neglect of the human aspect. After all, humans use and manage soil stocks. Therefore, the knowledge, skills, and behavior of soil users and managers should be important considerations and components of soil security initiatives. In other words, sustainable use and management of soils should be identified and framed on the basis of scientific knowledge balanced with an analysis of the prevailing behavior and practices of soil users and managers of different systems and contexts. A series of questions can be asked. What obligations do soil users 
or managers have? Which obligations can be imposed? What incentives are or need to be available? How do the incentives and obligations interact to drive sustainable use and management practices? Structural factors (e.g., policies or economic circumstances) can drive short- to long-term use and management practices that undermine soil security. As noted earlier, poor infrastructure or technology might limit the use of a given soil to its full potential. These factors should be important considerations in analyzing utilization of soils for soil security.

Sustainable use and management of soil stocks depend directly on the value put on soil. Soil is both a natural capital (biosystem providing ecosystem services and goods) and productive resource. To secure soils, it is important that soils are valued as natural capital (value rationality) and productive resource (instrumental rationality). The need to put an economic value on the soil itself and on its capability to conserve soil as natural capital has been suggested [15]. However, because the nature or characteristics of soil are not traded in markets, soil is hugely undervalued in economic terms. Hence, the value of soil as natural capital is given little consideration in the assessments of development projects or policy decisions. Decisions on the use and management of soil stocks are underpinned by values, rewards, and costs. Rewards and costs can be captured in economic valuations while values might not be adequately quantified in economic terms. Soil security should be approached from an ecocentric value system or paradigm. From this paradigm, conservation of soil as a natural capital is given priority consideration in all decisions involving soil stocks. This paradigm considers the maintenance of natural capital (and the totality of capital) as critical for economic sustainability. Thus, given the importance of soil as a biosystem underpinning human life, soil should be conserved for its own sake and for the good of humanity. Proceeding from this paradigm, soils can have both economic and non-economic values. Economic values should be explicit in the practical use and management of soil stocks with a view to serving conservation goals. Based on soil characteristics, capability, or conservation goals, hedonic pricing techniques or other methods used to assess the value of non-marketed goods (such as soil quality or capability) can be used to generate the economic value of soil for different purposes or uses, provide incentives, or impose obligations on users and managers to conserve soil stocks. The economic values so generated can be incorporated in the assessments of projects and policies, or guide decisions involving soil use and management. The non-economic values ought to be embedded in the value systems (set of deeply held beliefs that underpin actions, choices, and behaviors) of those using or depending on the soil stocks. This can be achieved by embedding a concept on the value of soil in general education and in the curricula on soil, environment, agriculture, natural resources, and heritage.

The utilization dimension embraces the "connectivity" introduced in [15], and expands the discussion to embrace land use systems, that is, the capacity of the given jurisdiction to effectively plan and manage land use to serve the goals of soil security. Land use and its dynamics are implicated in most of the current global challenges such as climate change and environmental degradation. Most, if not all, the threats to soils and development challenges can be linked to poor land use planning or inappropriate land use. Land use can either generate threats or amplify the threats to soil security. Yet, in an overwhelming number of countries, effective land use planning and management either has not appeared or has not been prioritized on the development agenda, and the international community is equally guilty. In most of these contexts, land use decisions are personal and land use changes of any kind occur over very short time scales. Soils are often a primary casualty of such changes and poor land use planning. Thus, getting a grip on land use and soil management, whether in urban or rural settings, arable or forest systems, is a critical step towards achieving soil security.

\subsection{Stability}

This regards the maintenance of the first three dimensions in a manner that serves short-term benefits and long-term goals. It embodies governance and sustainability issues regarding the first three dimensions. It concerns issues related to laws, policies, institutions, actors, norms, practices, research, education, communication, and technology that underpin availability, access, and utilization 
of soils. In other words, what governance mechanisms or tools are available or are required to keep the wheels of availability, accessibility, and utilization running efficiently and sustainably, and what are their dynamics?

Here, soil security and its dimensions can be conceptualized as interlocked and interacting units bounded by stability (Figure 1).

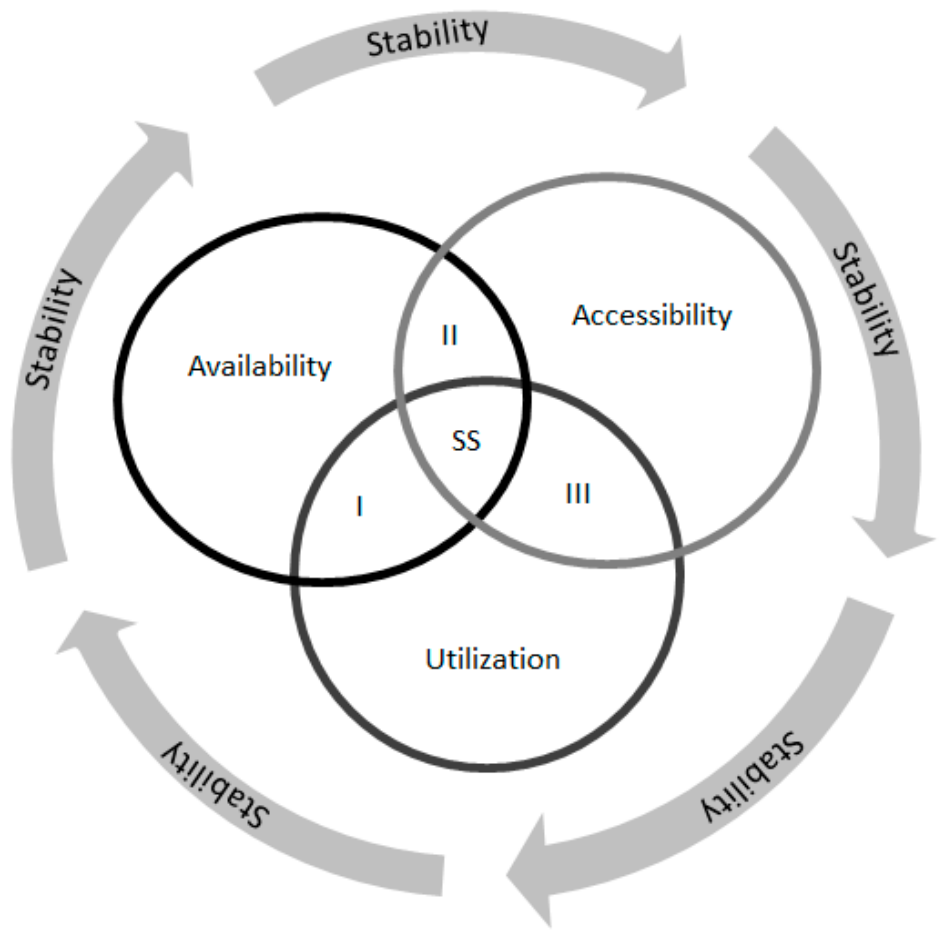

Figure 1. Conceptual relationships and interactions of the dimensions of soil security. Note: SS denotes soil security.

The interaction domain is crucial to understanding the system's behavior and making explicit some hidden issues that can impede functional solutions. The overall goal of soil security is to deliberately protect or safeguard the quality, quantity, and functionality of soil stocks. Interactions between the dimensions impact soil security. The interactive spheres (labeled I, II, and III in Figure 1) can generate implicit threats or raise different questions or opportunities that can lead to useful solutions. Interaction between availability and utilization (labeled "I" in Figure 1) brings forth issues of soil stewardship, which is a balance between use and conservation of available soil as a natural capital. The nature of the soil available affects its use, whereas utilization can affect availability. Availability of arable soils might dictate a productive use for crops, whereas crop production can degrade or shrink the availability of the soil. It is important to know whether, at a particular place and time, availability is driving a particular use or misuse and vice versa. Similarly, unregulated access to available soils can degrade or reduce the availability of soils as in the case of the commons. This intersection, labeled "II" in Figure 1, highlights issues in the abundance-scarcity continuum. Inequitable access to soils and unfair tenure systems can have adverse effects on availability. Availability (or scarcity) can have a push-pull effect on natural resource dependent populations. Between access and utilization (labeled "III"), issues regarding the value of soil as natural capital emerge. Access and utilization can influence each other in a positive or negative way (depending on the value system in operation), and ultimately affect soil security, especially in jurisdictions with a poor concept of value for non-marketable resources, poor land administration, and land use planning systems. In order to ensure soil security, appropriate questions have to be asked or analysis undertaken regarding the nature of the interactions among the dimensions (as these can constitute a source of threats) and their effects on soil security. 


\section{Discussion}

Soil security is a crucial component of human security as it underpins several aspects of human survival, including food, water, energy, climate change, and the environment in general. Securitizing soil can provide a frame for discourse and concerted action in response to the changing nature and scale of threats to global soil stocks. As indicated earlier, the purpose or goal of soil security should be to proactively and intentionally safeguard the availability of soil stocks in sufficient quality and quantity to sustain the generation of productive goods and ecosystem services. Progress towards achieving this goal can be managed, analyzed, and monitored through the proposed dimensions of soil security. Information generated from such exercise can inform discourse and high-level policy actions on soil security and, at the same time, make sense to lay audiences. These dimensions can also enable the integration of soil, water, and food security in a single framework.

Because of the complex and dynamic nature of soils, the interactions and relationships between soils, nature, and society, soil security requires a framework that is simple and intuitive, and that can be used to mobilize multi-actors (institutions, corporations, groups, and individuals) for a coherent, concerted action across varying administrative and temporal scales. Soil security exists when the availability of soil stocks in acceptable quality and quantity, the accessibility and sustainable utilization to generate productive goods, and ecosystem services are guaranteed. Monitoring progress towards soil security will require answers to questions related to the proposed dimensions (Table 1), which capture issues related to agronomic, environmental, and socio-economic use and management of soils. Answers to these questions over varying administrative or spatial and temporal scales will be instrumental in informing high-level policy and operational actions. Thus, policy- or decision-makers can ask such questions as: What is the quantity of soil (of a given type, quality, capability or condition) do we have? Are we using the soils appropriately and to their full potential? How much is being lost through what mechanisms or processes at a given time or spatial scale? What are the type, nature, and origin of threats facing the soils? In other words, are the threats critical or pervasive? How are the dimensions of soil security affected? In relation to addressing threats, an operational strategy would involve (i) identification of a core, fundamental set of attributes or properties that are vital to the availability, use, and functioning of a given soil stock; (ii) identification of critical and pervasive threats and their operational mechanisms to affect soil security dimensions; (iii) establishment of soil security governance structures for the management of soil security dimensions and associated threats.

Just as any biosystem, each given soil used for a particular purpose has a core set of vital attributes without which the soil cannot function or remain alive. This vital core can be a minimum set of physical, chemical, and biological attributes that enable the soil to serve a given function. Examples from arable soils can include organic carbon content, $\mathrm{pH}$, bulk density, aggregate stability, macrofauna, and microbial activity. These attributes and their spatial distribution make the soil available for target purposes, generate demand for the soil, and dictate utilization. Indicators or indices based on these attributes, or threshold values, can be developed to aid context-dependent monitoring. Related to this, a useful approach can be identified in the soil quality literature (see [28-30]). Moreover, capturing the economic and non-economic values of soil as a natural capital from an ecocentric paradigm will be crucial in conserving or securing soil stocks. The economic values of soil stocks, based on the vital core attributes, can serve as a strong basis for setting soil security goals at different administrative and temporal scales. The value of soil depends on the value system of those who manage or depend on the soil. In several jurisdictions, especially in low-income contexts, soil is not even considered as a natural resource. The management of soil in such contexts is, therefore, vaguely subsumed under a ministry of agriculture.

Next, critical and pervasive threats to soil stocks can be identified over varying scales or context. A threat is considered critical if it can potentially degrade the vital core and thereby render the soil stock dysfunctional or substantially reduce the quality or spatial coverage of soil stocks. A pervasive threat is widespread and potentially recurrent at the given scale. The operational mechanism of the threats (whether direct or indirect) is also important to know. The threats can originate from natural or 
anthropogenic sources. The threats diminish the availability, accessibility, and utilization of soil stocks. According to the European Commission, major threats to soil stocks include soil erosion, compaction, contamination, organic matter decline, salinization, landslides, and surface sealing [15,31]. While these can be classified as clear threats, focusing on threats this way might only address effects rather than causes and might not help address the vital core issues in specific contexts. It might also eliminate essential components of the solution such as land use or land tenure system, and miss the relationships among the threats and the sensitive domains (such as soil and food security). For example, surface sealing emanates from land use (notably, urbanization), which is related to all the dimensions proposed. Thus, this approach can eliminate the societal dimensions underpinning these threats from the analysis. We argue that, for the purpose of soil security, a starting point should be to ask the questions: What are the threats to stable or sustainable availability, accessibility, and utilization of soils in the given context? How critical or pervasive are the threats, and what are their origins? This approach will help identify and focus strategic and operational responses to the threats.

Finally, governance structures are required not only to manage the dimensions but also to prevent the materialization of identified threats, mitigate the adverse effects of active threats, and restore affected soil stocks. This aspect, related to the stability dimension, requires the creation of governance structures for soil security. Such protective mechanisms should be institutionalized (not episodic), responsive (flexible), preventative (not reactive), and dynamic [25] in relation to the nature and dynamics of the threats and the soil security dimensions in a given context. Education is a key, though not obvious, component of this governance structure. Education here is used in the broadest sense to include all forms and aspects intended to alter people's value systems, worldviews, and skills in favor of soil security. Without this, total effort of science, technology, law, and policy will only serve to further alienate people from soils and undermine soil security intentionally or unintentionally. As noted in [15], both scientists and those who manage or depend on soil should value soil. They should realize that they are part of the soil, and the soil is a primary biosystem that underpins their life. From an environmental value system perspective, an ecocentric paradigm will be appropriate to embed the value of soil into both private and public decisions and actions. Recent efforts, such as the Global Soil Partnership [14] and the Intergovernmental Science-Policy Platform on Biodiversity and Ecosystem Services (IPBES) Land Degradation Assessment, have attempted to drive soil security in a timely manner. The Sustainable Development Goals (SDGs) also provide timely opportunities for highlighting the pivotal role of soil security in development. Beyond ongoing global efforts, the international community ought to create instruments and conventions binding on governments and progress monitored robustly. It is worth surveying how many countries have soil conservation laws, as well as the extent to which soil is embedded in allied subjects at all levels of education.

As a people perceives an increasing resource scarcity, competition and use of the available resource are likely to intensify (Figure 1, interactive sphere III). In this sense, the need for soil security can be conceived of as akin to the turning of a screw. The perception of scarcity (availability) reinforces intense competition use (accessibility and utilization), which in turn speeds up or intensifies degradation, scarcity, inequity, injustice, and ultimately conflicts (stability). Economic development imperatives and urbanization, for example, put manifold pressure on soils available for agriculture and forest [8]. In jurisdictions where land administration and general governance systems are weak, arable lands are being lost rapidly to uses that can potentially make the soils permanently unavailable. This in turn reinforces competition for and intensive use of available arable and even marginal lands, resulting eventually in further degradation, a deepened sense of scarcity, displacements, and conflicts. These are also essential ingredients worthy of consideration in a governance framework for securing soils. Therefore, as competition and use of soil stocks intensify, so should governance structures be strengthened to protect and sustain the availability and use of soils. This requires a governance framework for mobilizing multiple institutions or actors for coherent action. 


\section{Conclusions}

Given the vital role of soils in human life and ecosystems, and the scale of the decline and threats to global soil stocks, there is an urgent need to take extraordinary measures to secure soils. To advance this discourse and enable action on soil security, a set of dimensions is needed to provide an organizing framework around which ideas, discourses, and concerted, coherent action can revolve. Securitization of resources is becoming overused and might lose its potency. In order to move from framing to discourse, and to keep the soil security discourse on a familiar terrain, we have proposed soil security dimensions similar to food security, which is already familiar to decision-makers and a wide range of stakeholders. The dimensions are availability (related to the quality and the spatial dimensions of soil stocks in a given context), accessibility (how the soil is made accessible), utilization (how the soils are used or can be used to generate optimal benefit), and stability (governance structures required to sustain the first three dimensions in a scientifically sound, socially just, and economically profitable manner). Progress towards soil security can be assessed through these dimensions. Identifying critical and pervasive threats and how they affect the soil's vital core and consequently the dimensions are key components of the strategies to maintain or guarantee a positive "soil balance sheet". What is even more urgent is an educational strategy required to alter people's value systems and worldviews on the overwhelming imperative to secure soils. The working definition and dimensions proposed in this paper can provide a basis for conceptualizing soil security and guide decision-makers in the prioritization of competing policy goals.

Acknowledgments: We thank Betty Araba Yawson for providing secretarial support and two anonymous reviewers for their constructive criticisms and insightful suggestions.

Author Contributions: David Oscar Yawson conceived the idea for the manuscript. David Oscar Yawson, Michael Osei Adu, Frederick Ato Armah, and Benjamin Ason wrote the manuscript. Frederick Ato Armah, Michael Osei Adu, and Genesis Tambang Yengoh retrieved literature and compiled bibliography. David Oscar Yawson, Michael Osei Adu, and Genesis Tambang Yengoh did the final editing and all authors commented on the final manuscript. Michael Osei Adu formatted the manuscript for submission.

Conflicts of Interest: The authors declare no conflict of interest.

\section{References}

1. Millennium Ecosystem Assessment. Ecosystems and Human Wellbeing: Synthesis; Island Press: Washington, DC, USA, 2005.

2. Blanco, H.; Lal, R. Soil and Water Conservation. In Principles of Soil Conservation and Management; Blanco, H., Lal, R., Eds.; Springer Science+Business Media B.V.: Dordrecht, The Netherlands, 2008; pp. 1-19.

3. Alexandratos, N.; Bruinsma, J. World Agriculture towards 2030/2050: The 2012 Revision; ESA Working Paper No. 12-03; FAO: Rome, Italy, 2012.

4. Food and Agriculture Organization (FAO). The State of Food Insecurity in the World: Economic Crises, Impacts and Lessons Learned; Report \#8-12; FAO: Rome, Italy, 2009.

5. Spring, Ú.O. Food as a new human and livelihood security challenge. In Facing Global Environmental Change: Environmental, Human, Energy, Food, Health and Water Security Concepts; Brauch, H.G., Spring, U..O., Grin, J., Mesjasz, C., Kameri-Mbote, P., Behera, N.C., Chourou, B., Krummenacher, H., Eds.; Springer: Berlin, Germany, 2009; pp. 471-500.

6. United Nations Development Programme (UNDP). Beyond Scarcity: Power, Poverty and the Global Water Crisis; Human Development Report; United Nations Development Programme: New York, NY, USA, 2006; p. 440.

7. Marcotullio, P.J.; Braimoh, A.K.; Onishi, T. Impact of urbanization on soil resources. In Land Use and Soil Resources; Braimoh, A.K., Vlek, P.L.G., Eds.; Springer: Dordrecht, The Netherlands, 2008; p. 10.

8. Lambin, E.F.; Meyfroidt, P. Global land use change, economic globalization, and the looming land scarcity. Proc. Natl. Acad. Sci. USA 2011, 108, 3465-3472. [CrossRef] [PubMed]

9. Lal, R. Managing soils and ecosystems for mitigating anthropogenic carbon emissions and advancing global food security. Bioscience 2010, 60, 708-712. [CrossRef]

10. Bai, Z.G.; Dent, D.L.; Olsson, L.; Schaepman, M.E. Proxy global assessment of land degradation. Soil Use Manag. 2008, 24, 223-234. [CrossRef] 
11. Quinton, J.N.; Govers, G.; Van Oost, K.; Bardgett, R.D. The impact of agricultural soil erosion on biogeochemical cycling. Nat. Geosci. 2010, 3, 311-314. [CrossRef]

12. Montgomery, D.R. Soil erosion and agricultural sustainability. Proc. Natl. Acad. Sci. USA 2007, 104, 13268-13272. [CrossRef] [PubMed]

13. Pimentel, D. Soil erosion: A food and environmental threat. Environ. Dev. Sustain. 2006, 8, 119-137. [CrossRef]

14. Global Soil Partnership (GSP). Global Soil Partnership: Strategic Objectives. Available online: http://www. fao.org/nr/water/landandwater_gsp.html (accessed on 27 December 2012).

15. McBratney, A.; Field, D.J.; Koch, A. The dimensions of soil security. Geoderma 2014, 213, 203-213. [CrossRef]

16. Roosevelt, F.D. Letter to All State Governors on a Uniform Soil Conservation Law. Available online: http:/ / www.presidency.ucsb.edu/ws/?pid=15373 (accessed on 12 December 2015).

17. Fischhendler, I.; Boymel, D.; Boykoff, M.T. How competing securitized discourses over land appropriation are constructed: The promotion of solar energy in the Israeli Desert. Environ. Commun. 2016, 10, 147-168. [CrossRef]

18. Gamson, W.A.; Modigliani, A. Media discourse and public opinion on nuclear power: A constructionist approach. Am. J. Sociol. 1989, 95, 1-37. [CrossRef]

19. Lakoff, G. Why it matters how we frame the environment. Environ. Commun. 2010, 4, 70-81. [CrossRef]

20. Davis, S.; Selin, C. Energy futures: Five dilemmas of the practice of anticipatory governance. Environ. Commun. 2012, 6, 119-136. [CrossRef]

21. Koch, A.; McBratney, A.; Adams, M.; Field, D.; Hill, R.; Crawford, J.; Minasny, B.; Lal, R.; Abbott, L.; O'Donnell, A.; et al. Soil security: Solving the global soil crisis. Glob. Policy 2013, 4, 434-441. [CrossRef]

22. Banwart, S. Save our soils. Nature 2011, 474, 151-152. [CrossRef] [PubMed]

23. Buzan, B.; Wæver, O.; De Wilde, J. Security: A New Framework for Analysis; Lynne Rienner: London, UK, 1998.

24. Wæver, O. Identity, integration and security: Solving the sovereignty puzzle in E.U. studies. J. Int. Aff. 1995, $48,389-431$.

25. Alkire, S. A Conceptual Framework for Human Security; Working Paper 2; Centre for Research on Inequality, Human Security and Ethnicity (CRISE); University of Oxford: Oxford, UK, 2003.

26. Koch, A.; McBratney, A.; Lal, R. Global soil week: Put soil security on the global agenda. Nature 2012, 492, 186. [CrossRef] [PubMed]

27. Friedemann, A. Peak Soil: Why Cellulosic Ethanol, Biofuels are Unsustainable and a Threat to America. 2007. Available online: http://www.culturechange.org/cms/content/view/107/1/ (accessed on 7 April 2016).

28. Karlen, D.L.; Andrews, S.S.; Doran, J.W. Soil quality: Current concepts and applications. Adv. Agron. 2001, 74, 1-39.

29. Karlen, D.L.; Ditzer, G.A.; Andrews, S.S. Soil quality: Why and how? Geoderma 2003, 114, 145-156. [CrossRef]

30. Andrews, S.S.; Karlen, D.L.; Mitchel, J.P. A comparison of soil quality indexing methods for vegetable production systems in Northern California. Agric. Ecosyst. Environ. 2002, 90, 25-45. [CrossRef]

31. Bouma, J.; Droogers, P. Translating soil science into environmental policy: A case study on implementing the EU soil protection strategy in the Netherlands. Environ. Sci. Policy 2007, 10, 454-463. [CrossRef]

(C) 2016 by the authors; licensee MDPI, Basel, Switzerland. This article is an open access article distributed under the terms and conditions of the Creative Commons Attribution (CC-BY) license (http://creativecommons.org/licenses/by/4.0/). 